\title{
Optimasi Kapasitas Armada Dengan Menggunakan Metode Linear Programming
}

\author{
Ilham Agus Mardiko ${ }^{1}$, Sulistyowati ${ }^{2}$, \\ 1,2 Jurusan Sistem Informasi - Institut Teknologi Adhi Tama Surabaya \\ Email: ${ }^{2}$ sulis tyowati@itats.ac.id
}

\begin{abstract}
PT. Indah Jaya Express is one company engaged in an expedition that has experience in handling their fields. With the activities of shipping and taking goods that are very dense, the company must determine the type and number of fleets used to carry out these activities. Manager need assist operational to determining the right type and number of fleets to used in serving shipping and picking-up requests and minimizing operational costs incurred by optimizing fleet load capacity. It builds the system using the Linear Programming method, a method that can optimize the fleet capacity. I do system testing in 2 ways, verification and validation tests. The results of the verification test between the system with QM software for Windows V5, there is an average difference of 34\% for shipping goods and 13\% for taking goods. While the results of the validation tests show a good cost savings in fleet fuel, which is an average of $49 \%$ for shipping goods and 38\% for taking goods, by testing the system 36 times. With the Linear Programming method, it can help the company's operations in optimizing the existing fleet capacity to minimize operational costs the company must incur that.
\end{abstract}

Keywords: optimization, linear programming, fleet capacity, goods expedition

Abstrak. PT. Indah Jaya Express merupakan salah satu perusahaan yang bergerak dalam bidang ekspedisi yang telah memiliki pengalaman dalam menangani bidangnya. Dengan aktifitas pengiriman maupun pengambilan barang yang sangat padat, perusahaan harus menentukan jenis dan jumlah armada yang digunakan untuk melakukan kegiatan tersebut. Oleh karena itu, perlu adanya suatu sistem aplikasi yang dapat membantu manajer operasional dalam menentukan jenis dan jumlah armada yang tepat untuk digunakan dalam melayani pengiriman dan permintaan pengambilan barang, serta dapat meminimalkan biaya operasional yang dikeluarkan dengan mengoptimalkan kapasitas muatan armada. Sistem yang dibangun menggunakan metode Linear Programming, sebuah metode yang dapat dimanfaatkan untuk mengoptimalkan kapasitas armada yang tersedia. Pengujian sistem dilakukan dengan 2 cara, yaitu uji verifikasi dan uji validasi. Hasil dari uji verifikasi antara sistem dengan software QM for Windows V5, terdapat selisih rata-rata 34\% untuk pengiriman barang dan $13 \%$ untuk pengambilan barang. Sedangkan hasil dari uji validasi yang telah dilakukan menunjukkan penghematan biaya bahan bakar armada yang baik, yaitu rata-rata $49 \%$ untuk pengiriman barang dan 38\% untuk pengambilan barang, dengan pengujian sistem sebanyak 36 kali pengujian secara acak. Dengan metode Linear Programming, tentunya dapat membantu operasional perusahaan dalam mengoptimalkan kapasitas armada yang ada guna meminimalkan biaya operasional yang harus dikeluarkan perusahaan.

Kata Kunci: optimasi, metode linear programming, kapasitas armada, ekspedisi barang

\section{Latar Belakang}

PT. Indah Jaya Express merupakan salah satu perusahaan yang bergerak dalam bidang ekspedisi yang telah memiliki pengalaman dalam menangani bidangnya. Pengiriman barang ke alamat-alamat yang dituju merupakan kegiatan rutin operasional perusahaan, begitu pula aktifitas pengambilan barang pada alamat yang telah ditentukan adalah salah satu dari bentuk layanan perusahaan terhadap pelanggan. Pada saat ini, perusahaan masih menggunakan cara manual untuk menentukan jenis dan jumlah armada yang digunakan untuk melakukan proses penghantaran dan pengambilan barang. Oleh karena itu, perlu adanya suatu sistem aplikasi yang dapat membantu perusahaan dalam menentukan jenis dan jumlah armada yang tepat untuk digunakan dalam melayani pengiriman dan permintaan pengambilan barang, serta dapat meminimalkan biaya operasional yang dikeluarkan dengan mengoptimalkan kapasitas muatan armada.

Sistem yang dibangun dengan memanfaatkan metode Linear Programming. Linear Programming merupakan sebuah teknik matematika yang didesain untuk mengalokasikan sumber daya yang tersedia, yang 
dapat membantu manajer operasi dalam merencanakan dan membuat keputusan untuk dapat mencapai target yang diinginkan (Sriwidadi \& Agustina, 2013). Pemrograman linier merupakan metode pemecahan masalah yang memiliki tiga komponen dasar antara lain variabel keputusan, tujuan, dan kendala. Penggunaan pemrograman liner banyak digunakan pada proses produksi dimana proses produksi perusahaan untuk memenuhi kebutuhan produk, keuntungan (laba), kualitas, dan penggunaan sumber daya perusahaan yang ada (Erfianti \& Muhaijir, 2020). Dari latar belakang diatas peneliti menentukan topik penelitian bagaimana memanfaatkan pemrograman linier pada optimasi kapasitas armada.

\section{Tinjauan Pustaka}

\subsection{Optimasi dan Programa Linier}

Optimasi adalah usaha memaksimalkan kegiatan sehingga keuntungan yang ingin dicapai dapat terwujud (Ali, 2014). Optimasi dapat juga diartikan sebagai aktivitas untuk mendapatkan hasil terbaik di bawah keadaan yang diberikan yang menjadi ukuran dimana semua kebutuhan dapat terpenuhi dari kegiatankegiatan yang dilaksanakan dengan memanfaatkan sumber daya yang tersedia. Model program linier digunakan untuk menunjukkan proses model yang menjadikan sumber daya sebagai kumpulan batasan dalam usaha untuk mencapai subjek tujuan (Sudarsana, 2009). Linear programing sangat berguna untuk mencapai hasil yang optimum dalam mengalokasi sumber-sumber produksi (Fardiana, 2012).

Program linier merupakan sebuah teknik matematika yang didesain untuk mengalokasikan sumber daya yang tersedia, yang dapat membantu manajer operasi dalam merencanakan dan membuat keputusan untuk dapat mencapai target yang diinginkan (Sriwidadi \& Agustina, 2013).Program linier juga merupakan salah satu teknik Operating Research yang digunakan paling luas dan diketahui dengan baik. Bentuk umum program linier adalah sebagai berikut :

Fungsi tujuan :

Maksimumkan atau minimumkan $\mathrm{z}=\mathrm{c} 1 \mathrm{x} 1+\mathrm{c} 2 \mathrm{x} 2+\ldots+\operatorname{cnxn} \ldots \ldots \ldots \ldots \ldots \ldots$

Sumber daya yang mambatasi :

$\mathrm{a} 11 \mathrm{x} 1+\mathrm{a} 12 \mathrm{x} 2+\ldots+\mathrm{a} 1 \mathrm{nxn}=/ \leq / \geq \mathrm{b} 1$

$\mathrm{a} 21 \mathrm{x} 1+\mathrm{a} 22 \times 2+\ldots+\mathrm{a} 2 \mathrm{nxn}=/ \leq / \geq \mathrm{b} 2$

$\mathrm{am} 1 \mathrm{x} 1+\operatorname{am} 2 \mathrm{x} 2+\ldots+\operatorname{amnxn}=/ \leq / \geq \mathrm{bm}$

dengan :

$\mathrm{x} 1, \mathrm{x} 2, \ldots, \mathrm{xn} \geq 0$

Simbol x1, x2, .., xn (xi) menunjukkan variabel keputusan. Jumlah variabel keputusan (xi) oleh karenanya tergantung dari jumlah kegiatan atau aktivitas yang dilakukan untuk mencapai tujuan. Symbol c1, $\mathrm{c} 2, \ldots, \mathrm{cn}$ merupakan kontribusi masing-masing variabel keputusan terhadap tujuan, disebut juga koefisien fungsi tujuan pada model matematikanya. Symbol a11, ..., aln, ..., amn merupakan penggunaan per unit variabel keputusan akan sumber daya yang membatasi, atau disebut juga sebagai koefisien fungsi kendala pada model matematiknya. Simbol b1, b2, .., bm menunjukkan jumlah masing-masing sumber daya yang ada. Jumlah fungsi kendala akan tergantung dari banyaknya sumber daya yang terbatas. Permasalahan linear programming dapat diselesaikan dengan menggunakan metode eliminasi. Dengan menggunakan metode ini, terlebih dahulu harus mengiliminasi/menghilangkan salah satu variabel dengan cara penjumlahan ataupun pengurangan. Untuk lebih jelasnya perhatikan contoh berikut :

Tentukan himpunan selesaian dari sistem persamaan linear dua variabel yang memuat persamaan-persamaan $2 x+5 y=-3$ dan $3 x-2 i=5$.

Untuk menentukan selesaiannya, pertama harus mengeliminasi salah satu variabelnya. Misalkan mengeliminasi variabel $x$, maka kita harus menyamakan koefisien $x$ dari kedua persamaan tersebut. Koefisien $x$ pada persamaan 1 dan 2 secara berturut-turut adalah 2 dan 3 . Sehingga harus menyamakan koefisien $x$ dari kedua persamaan tersebut menjadi KPK (Kelipatan Persekutuan Terkecil) dari 2 dan 3, yaitu 6, dengan mengalikan persamaan 1 dengan 3 dan persamaan 2 dengan 2 .

\begin{tabular}{l|l|l|}
$2 x+5 y=-3$ & $\mathrm{x} 3$ & $6 x+15 y=-9$ \\
$3 x-2 y=5$ & $\mathrm{x} 2$ & $6 x-4 y=10$
\end{tabular}




$$
\begin{aligned}
19 & =-19 \\
y & =-19 / 19=-1
\end{aligned}
$$

Dengan cara yang sama, selanjutnya mengeliminasi variabel $y$ untuk mendapatkan nilai dari $x$.

$$
\begin{array}{l|l|l}
2 x+5 y=-3 & \mathrm{x} 2 & 4 x+10 y=-6 \\
3 x-2 y=5 & \mathrm{x} 5 & 15 x-10 y=25 \\
& \\
& x=19 / 19=1
\end{array}
$$

Sehingga diperoleh penyelesaiannya adalah $x=1$ dan $y=-1$, atau dapat dituliskan sebagai himpunan selesaian $\mathrm{Hp}=\{(1,-1)\}$.

\subsection{UML (Unified Modeling Language)}

Unified Modeling Language (UML) adalah alat bantu analisis serta perancangan perangkat lunak berbasis objek (Nugroho, 2006). Unified Modeling Language (UML) merupakan standard modeling language yang terdiri dari kumpulan-kumpulan diagram, dikembangkan untuk membantu para pengembang sistem dan software agar bisa menyelesaikan tugas-tugas seperti : Spesifikasi, Visualisasi, Desain Arsitektur, Konstruksi, Simulasi dan testing serta Dokumentasi. Bagian utama dari UML antara lain adalah sebagai berikut : Use case Diagram., Sequence Diagram, Activity Diagram, dan Class Diagram. UML banyak digunakan oleh peneliti dalam mengembangkan desain sebuah aplikasi. Ilamsyah, dkk, tahun 2020, pada penelitiannya menggunakan UML dalam pengembangan aplikasi sistem informasi inventory barang yang terdapat pada PT. Anugrah Distributor Indonesia. Disini peneliti menggunakan UML untuk membuat use case diagram, activity diagram, diagram sequence (Ilamsyah et al., 2020).

Turki Salim, dkk, tahun 2020, menggunakan UML dalam mengembangkan desain aplikasi sistem distribusi hasil produksi obat. Peneliti menggunakan UML untuk membuat use case diagram, actiity diagram, dan sequence diagram. Pada penelitian ini berhasil dikembangkan aplikasi sistem distribusi obat, dimana pada awalnya proses distribusi dilakukan secara manual dan setelah aplikasi dikembangkan oleh peneliti, proses distribusi dilakukan dengan menggunakan aplikasi digital (Salim et al., 2020). Sri Rahayu, dkk, tahun 2020, pada penelitiannya mengembangkan aplikasi sistem monitoring perencanaan resiko pembangunan kantor sipil. Aplikasi ini didesain oleh peneliti dengan menggunakan UML. Aplikasi yang dibangun berbasiskan web. Pada penelitian ini pemanfaatan UML untuk mendesain sistem terbagi menjadi beberapa bagian, yaitu use case diagram, sequence diagram, activity diagram, state chart diagram, dan class diagram. Aplikasi telah berhasil dibangun dan dimanfaatkan oleh kantor dinas pendidikan kabupaten Tangerang (Rahayu et al., 2020).

\section{Metode}

Pada penelitian ini, peneliti membagi menjadi lima kegiatan besar, yaitu survey, wawancara, desain aplikasi, pembuatan aplikasi, dan implementasi sistem, dimana kegiatan penelitian ini dapat dilihat pada gambar 1 .

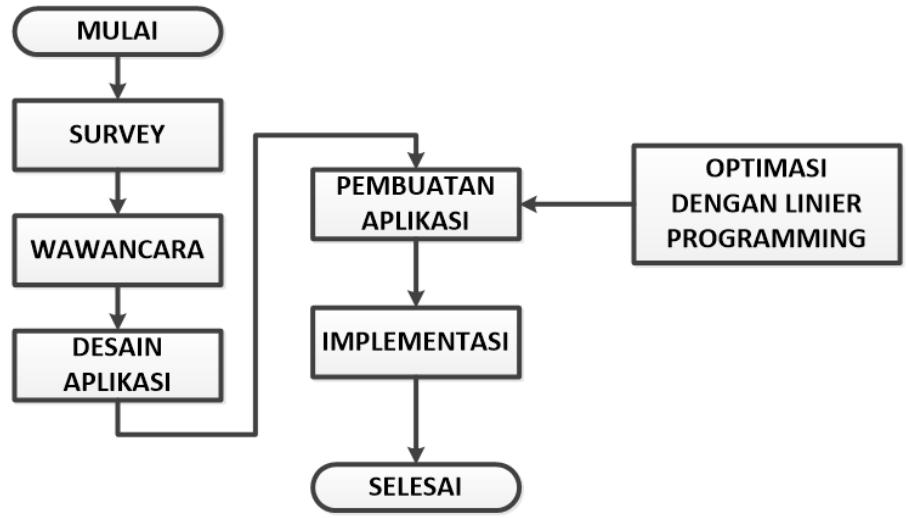

Gambar 1. Rencana Penelitian Yang dilakukan peneliti 
Survey kami lakukan pada PT. Indah Jaya Express cabang Surabaya. Pada saat survey kami bertemu dengan manajer operasional untuk melakukan wawancara mengenai kondisi kegiatan PT. Indah Jaya Express. Saat wawancara kami mendapatkan informasi bahwa proses penentuan jenis dan jumlah armada selama ini masih dilakukan secara manual. Proses manual yang dimaksud adalah bagian customer service menerima order pengambilan barang, lalu supervisor membuka data pengiriman dan pengambilan barang, supervisor membagi pengiriman dan pengambilan barang berdasarkan wilayah yang telah ditentukan dan bagian terakhir adalah courier melakukan pengiriman atau pengambilan barang. Proses ini dapat dilihat pada gambar 2 .

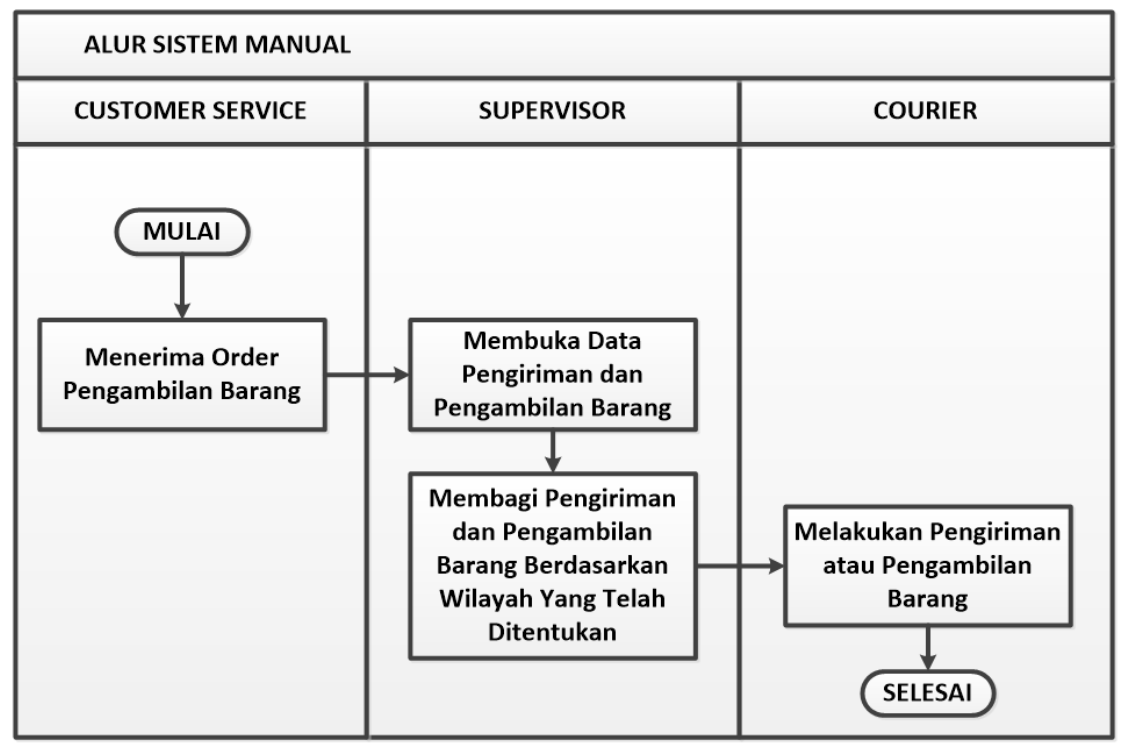

Gambar 2. Alur Sistem PT. Indah Jaya Express Sebelum Aplikasi Di Implementasikan

Dari kondisi seperti gambar 2 diatas, akhirnya kami mengusulkan suatu sistem baru bagi PT. Indah Jaya Express cabang Surabaya. Dimana terdapat aplikasi yang membantu pihak manajerial dalam melakukan proses pengiriman dan pengambilan barang dengan menggunakan linier programming. Dari sisi Supervisor langsung mendapatkan hasil optimasi yang dilakukan aplikasi sehingga proses pengiriman dan pengambilan barang dapat lebih efektif. Sistem yang dialurkan dapat dilihat seperti pada gambar 3 .

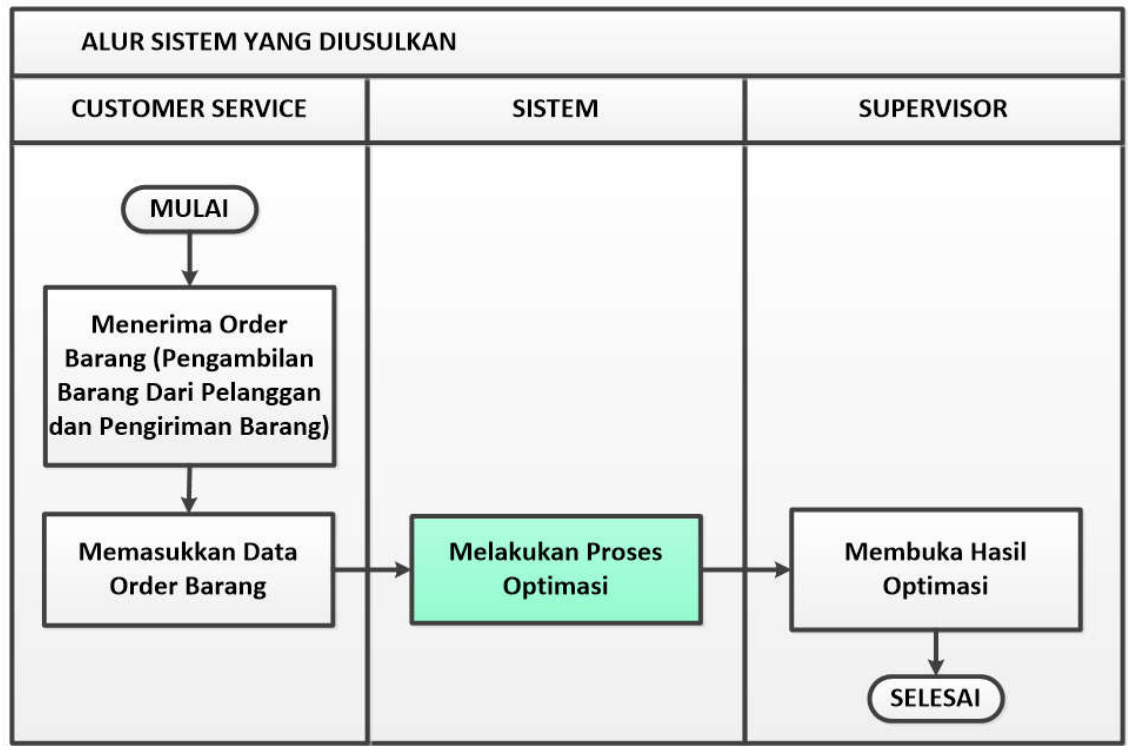

Gambar 3. Sistem Aplikasi Optimasi Yang Ditawarkan Peneliti Ke PT. Indah Jaya Express 
Desain aplikasi secara keseluruhan dapat dilihat seperti gambar 4 dimana dapat diketahui hal-hal yang dapat dilkaukan oleh Customer Service dan Supervisor. Terdapat tiga kegiatan yang dapat dilakukan oleh Customer Service, yaitu input data Order pengambilan barang, login dan input data resi pengiriman barang. Untuk supervisor dapat melakukan tiga kegiatan juga, yaitu login, menghitung proses optimasi, dan manajemen data.

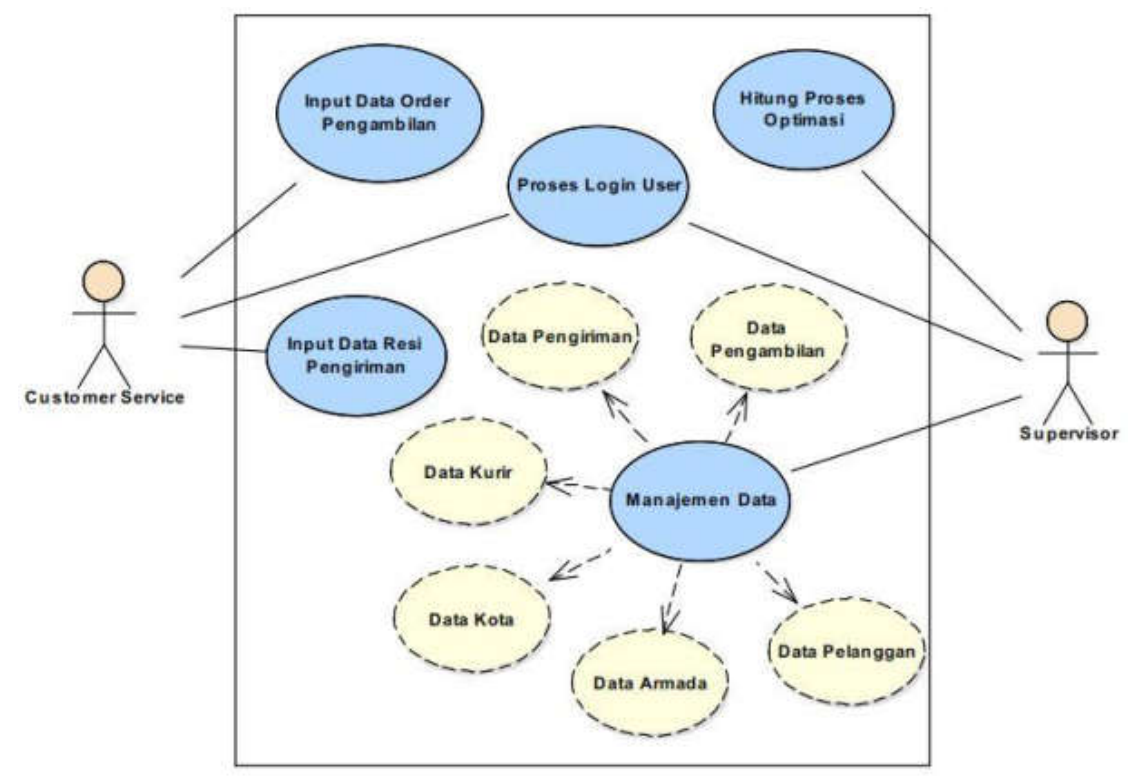

Gambar 4. Use Case Diagram dari Sistem Aplikasi Yang Diusulkan Peneliti.

Untuk desain prototype aplikasi dapat dilihat pada gambar 5. Pada gambar 5 merupakan prototyype untuk form login bagi customer service dan supervisor.

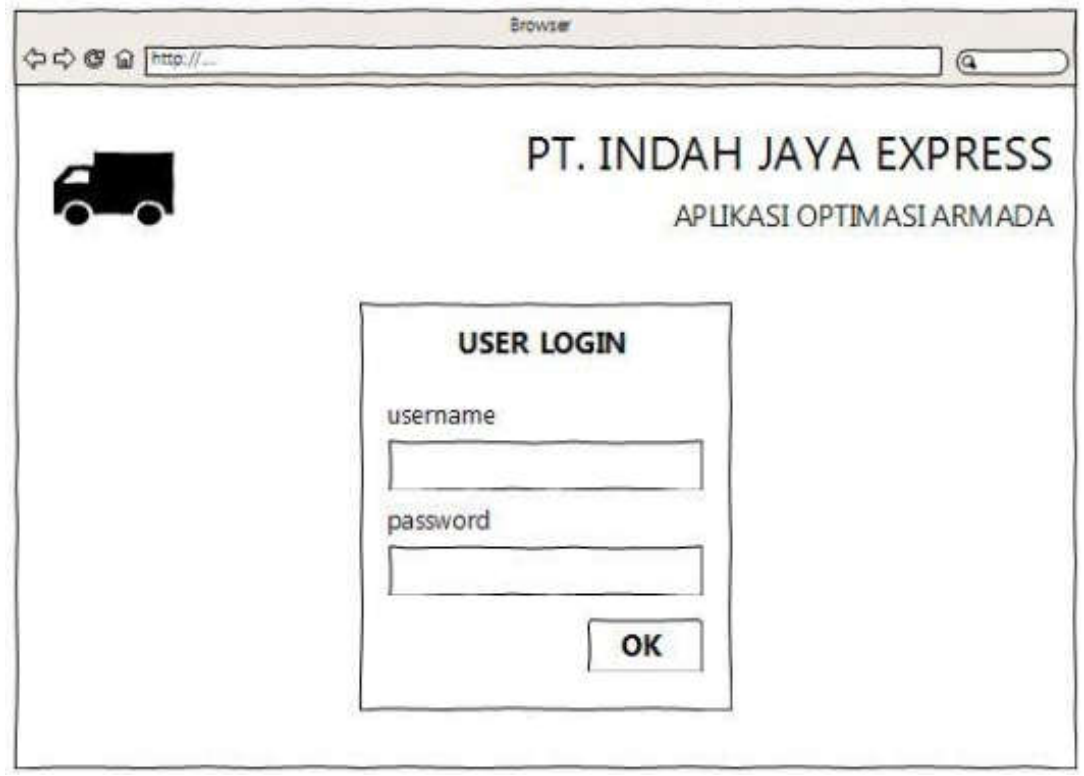

Gambar 5. Prototype Desain Aplikasi.

Pada gambar 6. Merupakan gambar untuk Prototype desain aplikasi bagian optimasi armada PT. Indah Jaya Ex[ress. Pada gambar 6 dapat diketahui bahwa bagian supervisor hanya melakukan proses Hitung untuk mengetahui proses optimasi yang dilakukan oleh aplikasi. 


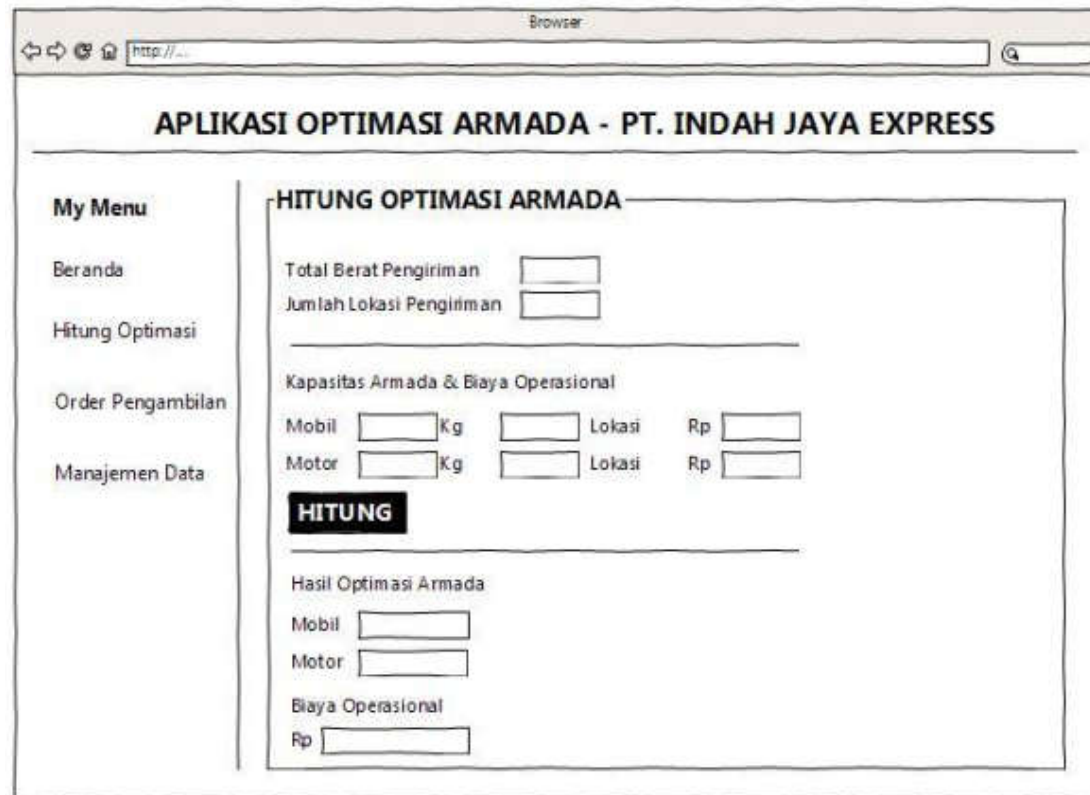

Gambar 6. Prototype Desain Aplikasi Optimasi Armada PT. Indah Jaya Express.

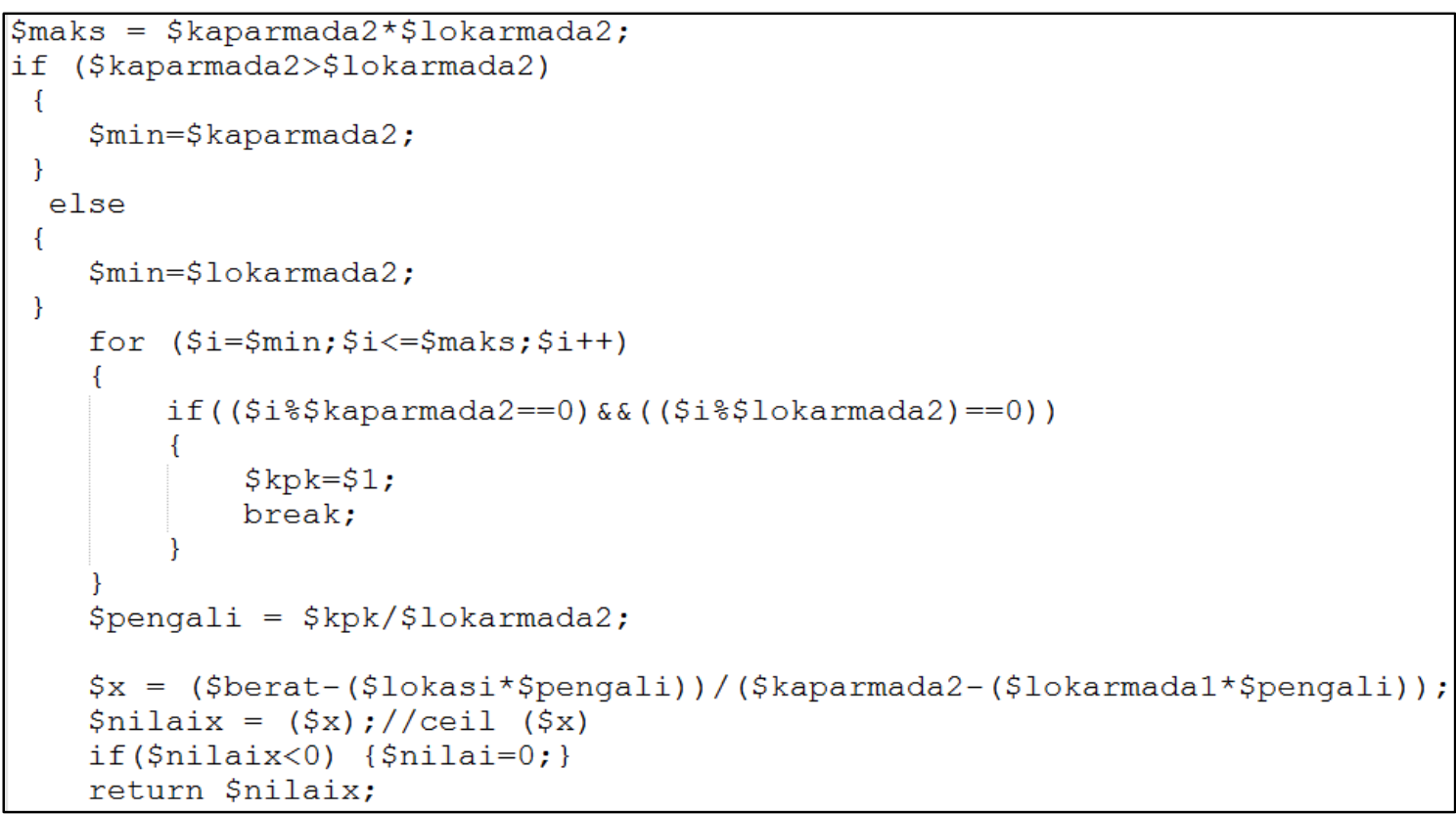

Gambar 7. Cuplikan program perhitungan optimasi pengambilan barang

\section{Kesimpulan}

Dari kegiatan penelitian ini dapat disimpulkan beberapa hal antara lain:

1. Peneliti telah mampu mengembangkan aplikasi optimasi pengiriman dan penerimaan armada dengan menggunakan metode optimasi liner programming.

2. Aplikasi telah diuji dan diimplementasikan pada PT. Indah Jaya Express cabang Surabaya.

3. Aplikasi yang dibangun telah mampu mengurangi biaya operasional perusahan sebesar $49 \%$ untuk pengiriman barang dan $38 \%$ untuk pengambilan barang. 


\section{Referensi}

Ali, M. A. (2014). ANALISIS OPTIMALISASI PELAYANAN KONSUMEN BERDASARKAN TEORI ANTRIAN PADA KALTIMGPS.COM DI SAMARINDA. EJournal Ilmu Administrasi Bisnis, 2(3), 346-357.

Erfianti, R., \& Muhaijir, M. N. (2020). Optimasi Produksi Hijab Menggunakan Program Linear Multi Objective Fuzzy. JAMBURA JOURNAL OF MATHEMATICS, 2(1), 22-29.

Fardiana, E. (2012). Maksimalkan Keuntungan Pada Toko Kue Martabak Doni Dengan Metode Simpleks. UG Jurnal, 6(09), 11-14.

Ilamsyah, Rahayu, S., \& Lisnawati, D. (2020). Prototype Aplikasi Analisa Sistem Informasi Inventory Barang Pada PT Anugrah Distributor Indonesia. ICIT (Innovative Creative and Information Technology) Journal, 6(1), 50-60. https://doi.org/10.33050/icit.v6i1.860

Nugroho, A. (2006). Analisis dan Perancangan Sistem Informasi Dengan Metodologi Berorientasi Objek.

Rahayu, S., Faris, M. R., \& Pane, A. R. (2020). Monitoring System Building Plan For Risk Of Civil Office (Case Study: Tangerang Regency Of Education). ATM Journal, 4(1), 57-66.

Salim, T., Yusup, M., \& Sukamto, D. L. (2020). Rancang Bangun Sistem Distribusi Hasil Produksi Obat Untuk Menjamin Kualitas Dalam Meningkatkan Pelayanan Pelanggan. Journal CERITA, 6(1), 26-38.

Sriwidadi, T., \& Agustina, E. (2013). ANALISIS OPTIMALISASI PRODUKSI DENGAN LINEAR PROGRAMMING MELALUI METODE SIMPLEKS. Binus Business Review, 4(2), 725-741.

Sudarsana, D. K. (2009). Optimalisasi Jumlah Tipe Rumah Yang Akan Dibangun Dengan Metode Simpleks Pada Proyek Pengembangan Perumahan. Jurnal Ilmiah Teknik Sipil, 13(2), 183191. 